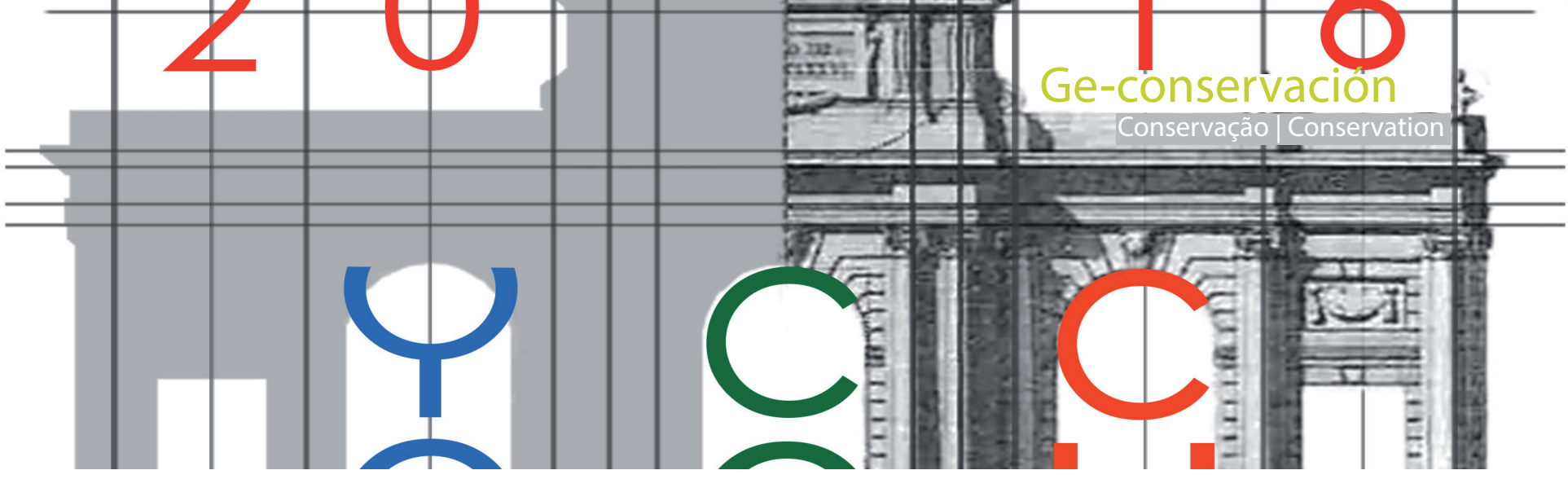

\title{
Influence of the calcination process in traditional gypsum with structural behavior
}

\author{
Pedro Bel-Anzué, Antonio Almagro, Maria Paz Sáez Pérez, Carlos Rodriguez-Navarro
}

\begin{abstract}
Gypsum is used as a finishing material with a principal aesthetical purpose. It is assumed that this binder has a poor structural behavior. However, it is also found as a structural material in many ancient constructions. In Spain there are several examples of architectural heritage with structures, floors and façades made of pure gypsum. In the studied area (Teruel), traditional gypsum represents the main material used in its architectural heritage. Nowadays, commercial gypsum is being used in restorations, but the different behavior between current and traditional gypsum results in non-compatible restorations. Here, we analyze the traditional gypsum calcination process by building two traditional ovens, assisted by locals masons, and we study how the differences in the calcination procedure can generate different gypsum products, which can be used either as a finishing material or as a structural material with a high mechanical resistance.
\end{abstract}

Key words: calcination, structural, traditional, gypsum, oven construction.

\section{Influencia del proceso de calcinación del yeso trasicional para uso estructural}

Resumen: El yeso se utiliza como un material de acabado con una función principalmente estética. Se le asume un pobre comportamiento estructural. Sin embargo, también se encuentra como material estructural en muchas construcciones antiguas. En España hay numerosos ejemplos de patrimonio arquitectónico con las estructuras, los suelos y fachadas de yeso puro. En la zona estudiada (Teruel), el yeso tradicional representa el principal material utilizado en su patrimonio arquitectónico. Hoy en día, el yeso comercial está siendo utilizado en las restauraciones, pero el diferente comportamiento entre el yeso actual y el tradicional, está produciendo restauraciones no compatibles. Aquí se analizan las fases de calcinación del yeso construyendo dos hornos, asistidos por dos artesanos locales, estudiando como las diferencias del proceso de calcinación pueden generar diferentes productos de yeso, obteniendo un material de acabado o un material estructural de alta resistencia mecánica.

Palabras clave: calcinación, estructural, tradicional, yeso, construcción de horno.

\section{Introduction}

The current perception regarding the use and performance of gypsum as a building material is that a poor mechanical behavior is expected. However, historically, traditional gypsum elaborated in traditional ovens, was used as a structural material in countless ancient constructions (Almagro 1986). In Spain, in the East and South areas of the Iberian Peninsula (Tarragona, Barcelona, Lérida, Zaragoza, Huesca, Teruel, Castellón, Valencia, Cuenca, Albacete, Murcia, Alicante Almeria, Jaen, Granada Málaga and Sevilla) (Rubio 2006). Examples of such structural applications of gypsum include:
-Structural massive walls: "Torres Mudejares" in Teruel or the castles from Calatayud, Maluenda, Cadrete and "Salón del Cuco" in Burbáguena. (BelAnzué 2016) [figure 1].

\section{- Structural nerves: Cathedral of Zaragoza's "Seo" and} Cathedral of Tarazona.

—Façades made of pure gypsum: historical centers of Albarracin, Cuenca, Madrid, and Valencia (Mileto 2011; La Spina 2015).

Specific conditions during the processing and calcination of gypsum-based materials can yield different products 

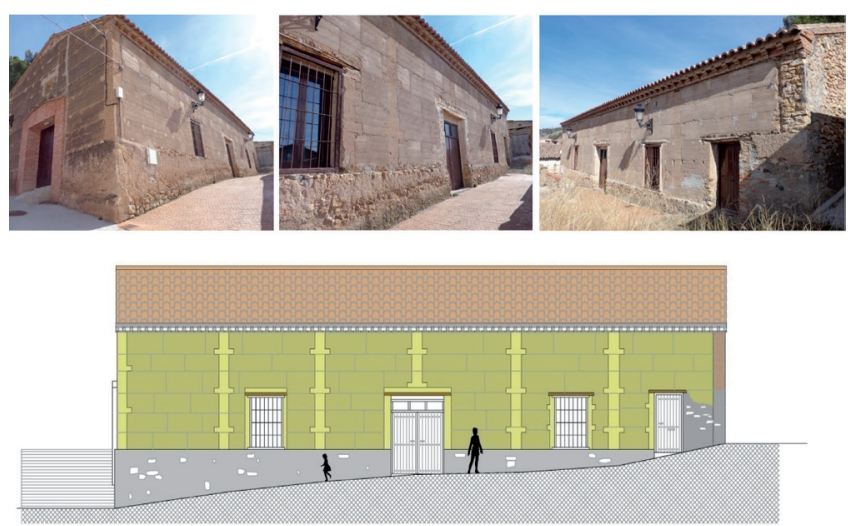

Figure 1.- "Salón del Cuco" construction placed in Burbáguena made with columns of pure gypsum.

despite the fact that the initial original material is always raw gypsum stone $\left(\mathrm{CaSO}_{4} \cdot 2 \mathrm{H}_{2} \mathrm{O}\right)$ [Table 01]. As a result, a large number of multi-product mixtures can be obtained (Bel-Anzue et al., in press). Depending on the calcination by-product(s), the behavior of set gypsum (after re-hydration) can fluctuate. For example, it has been observed that set a-hemihydrate can obtain a four times higher compression strength than concrete (Arredondo 1961; Ye 2011). Unfortunately, once rehydrated, the estimation of the mineralogical composition of the original calcined product is nearly impossible. This is a strong handicap to precisely reproduce the properties of gypsum used in the past.

In view of the current demand of gypsum for heritage restoration/conservation interventions, we focused our research on how to achieve a calcined product with properties as similar as those of structural gypsum elaborated in the past (Singh, 2007) (Freier, 2003). For this task, we analyzed the traditional production of gypsum by replicating the construction of two ovens built according to the different ancient traditions transmitted over generations in the area of Teruel.

Here we define how traditional ovens are dimensioned and constructed and how such evidence enable us to parameterize the conditions (temperature, pressure and moisture) during the calcination process and to establish the relationship between these parameters and the final product properties. This research thus represents the first step for improving our current knowledge on the traditional use of gypsum as a structural material and has implications in the future use of gypsum in heritage conservation.

\section{Methods}

- Phase 1: Building new ovens, according to traditional procedures.

\section{a) Bibliographical revision}

Some ethnographers and researchers such as Maorad (2002) or Monesma (2006) published researches describing gypsum calcination using traditional ovens in the studied area, and we contrasted it with the knowhow from the masons.

\section{b) Interview with Old masons}

Different local old masons such as Maximiano Malo, Santiago Bailón, Ignacio Bailón, Pepe Rodrigo, Esteban López, Antonio Mena, who were involved in the production of gypsum using traditional ovens until ca. 1950 were interviewed. They inherited this knowledge from their families. Basically, such a know-how has been communicated from parents to children for generations. However, in some areas this "transmission" of knowledge has been lost.

c) Study of remaining ovens and industry of gypsum production

In the gypsum quarry of "Navarrete del Rio" it has been possible to locate the existence of 24 similar "primitive" gypsum ovens made of gypsum stones or just a hollow (or trench) dug on a sloped terrain. In the region of Leciñena (Zaragoza) five more traditional ovens were found, one of them completely set to be fired and another already

Table 1.- T-dependent products obtained after the calcination of raw gypsum. (MNCARS).

\begin{tabular}{lll}
\hline Calcination T & Mineral phase & Name \\
\hline $120-180^{\circ} \mathrm{C}$ & $\rightarrow \mathrm{CaSO}_{4} \cdot 1 / 2 \mathrm{H}_{2} \mathrm{O}$ & $\rightarrow$-hemihydrate \\
\hline $100-120^{\circ} \mathrm{C}$ (autoclave oven, $\uparrow$ Pressure) & $\rightarrow \mathrm{CaSO}_{4} \cdot 1 / 2 \mathrm{H}_{2} \mathrm{O}$ & $\rightarrow$-hemihydrate \\
\hline $220-380^{\circ} \mathrm{C}$ & $\rightarrow \mathrm{CaSO}_{4}$ & $\rightarrow$ anhydrite III- Soluble \\
\hline $380-1200^{\circ} \mathrm{C}$ & $\rightarrow \mathrm{CaSO}_{4}$ & $\rightarrow$ anhydrite II - Not soluble \\
\hline $1200-1350^{\circ} \mathrm{C}$ & $\rightarrow \mathrm{CaSO}_{4}$ & $\rightarrow$ anhydrite I \\
\hline$>1350^{\circ} \mathrm{C}$ & $\rightarrow \mathrm{CaO}+\mathrm{SO}_{2}$ & $\rightarrow$ hydraulic gypsum \\
\hline
\end{tabular}



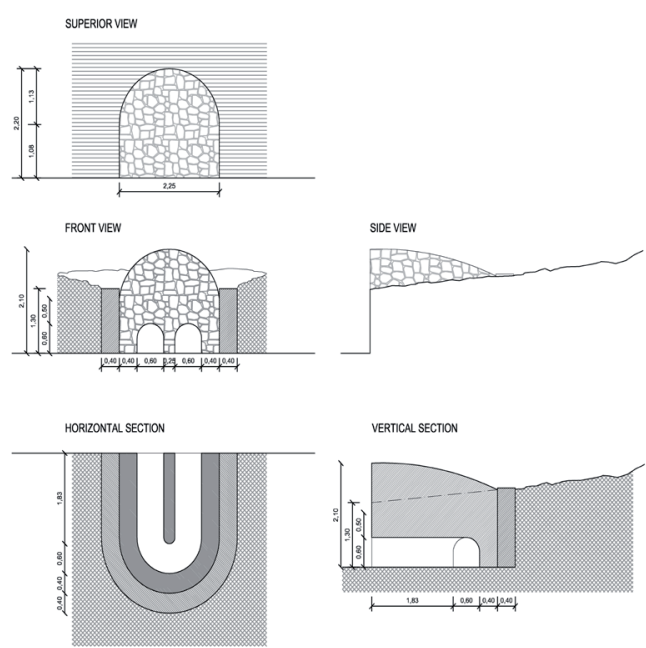

Figure 2.- Morphology and dimensions of a representative gypsum oven in the area. (MNCARS).

calcined, but still standing [figure 2]. All of them displayed very similar morphology and dimensions.

We also found additional gypsum ovens with analogous design and dimensions in Belchite (Zaragoza), La Almunia (Zaragoza), La Almolda (Zaragoza), Arenas del Río (Granada), and Baza (Granada).

In some of these towns (Leciñena, La Almunia, Calatayud, Navarrete) with historical gypsum quarries and primitive traditional ovens, we also found a technology development implemented since 1950 (aprox) and involving the use of new materials as concrete for the sep up of the ovens, or to increase the size of the combustion area.

- Phase 2: Obtaining the material for combustion.

In the studied literature from ethnographers and researchers, we found references on the quantity and type of wood used for firing. Such information was compared with that provided by the local masons.

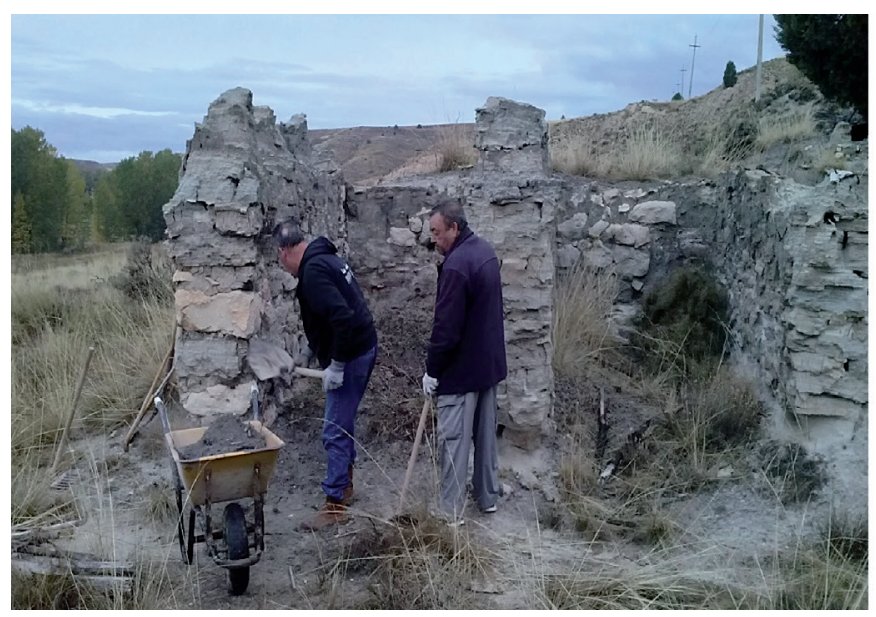

- Phase 3: Combustion monitoring.

The selection of the right monitoring instruments was problematic because this experiment was never done before. Indeed, a great uncertainty existed regarding what would be the maximum temperature reached during calcination in traditional gypsum ovens. The ranges ( $T$, $\mathrm{pCO}_{2}, \mathrm{pH}_{2} \mathrm{O}$ ) to monitoring in situ the calcination procedure required the cooperation of various experts in the field of measurement and monitoring.

- Phase 4: The role of masons during the calcination procedure

Gypsum production was a manual process with an important component of knowledge transmitted for generations, involving non-absolute measurements and relaying on a variable (empirical) calcination control. Each family of masons had some know-how or recipe that allowed them produce a different product. In this respect, a bibliographical research was conducted in parallel with masons interviews.

\section{Results}

- Phase 1: Building new ovens, according to traditional procedures.

The outcome of our ethno-historic research and the interviews with the old masons showed that the most commonly used oven in the area was a simple excavation called "casa". This so-called "casa" (house) was a trench dug on a sloped terrain with square proportions of approximately $2.5 \times 2.5 \mathrm{~m}$, with three sides dug into the hillside, and a height of $2 \mathrm{~m}$.

For our purposes, and to ensure the correct size and temperature distribution during the calcination process, we restored to the correct proportions the remains of a former oven made of gypsum stones and located in a gypsum quarry [figure 3].

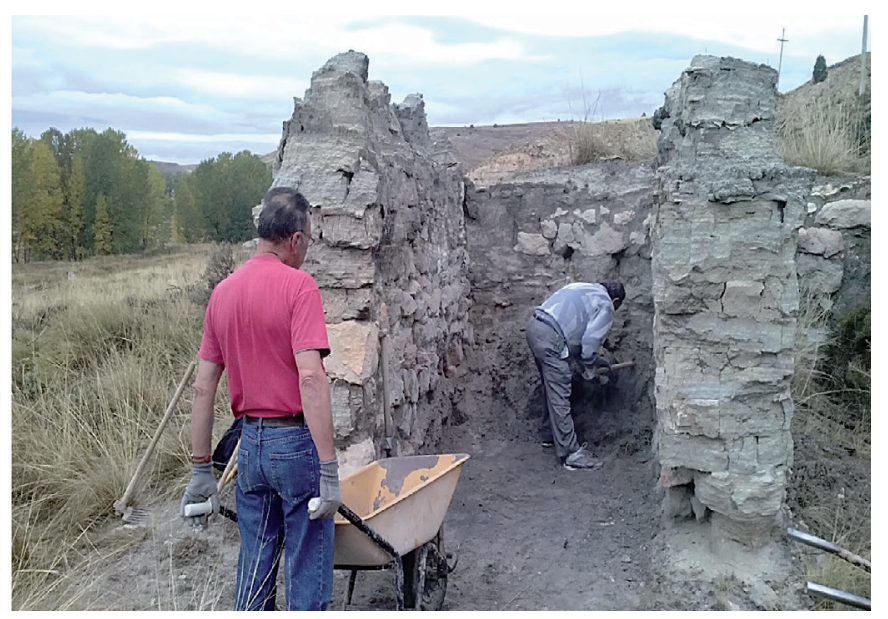

Figure 3.- Remains of a former oven in Navarrete. 

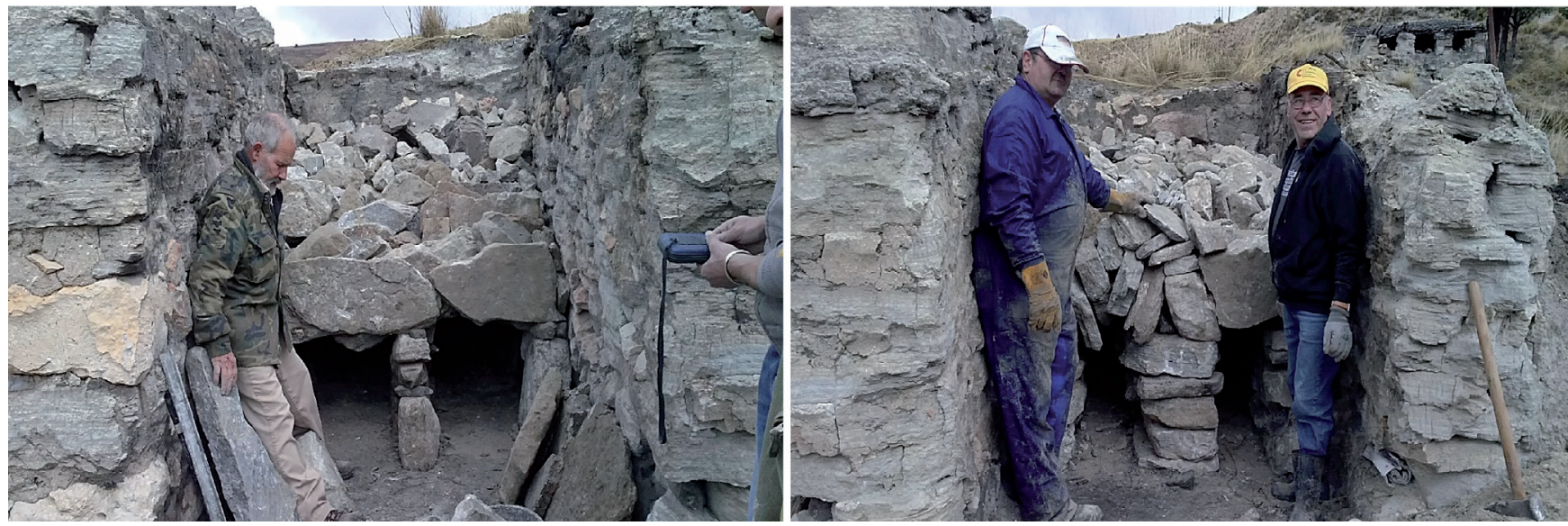

Figure 4.- Old masons placing gypsum stones in the oven, Navarrete.

In placing gypsum stones, the experience of the old masons was extremely important: The stones with larger size and density were placed at the bottom part of the oven to withstand the weight of the other pieces as well as the most intense fire. These stones were placed in the lowest and central portions of the oven, as well as in the areas around the fire [figure 4]

- Phase 2: Obtaining the material for combustion.

In several towns from the studied area, the material for combustion was collected from the surroundings. In general, the majority of the species used as fuel were bushes of rapid growth with a high combustion power that could be freshly cut a day before the calcination begins. The specie most frequently used is Genista scorpius, but the following are also employed: Rosmarinus officinalis, Quercus coccifera, Salsola vemiculata, and Santolina chamaecyparissus.

From these kinds of bushes, masons cut 70 bushels of 35 $\mathrm{kg}$ each. Approximately $2.450 \mathrm{~kg}$ of this type of fuel were placed in each oven.

We also found some towns in the area (such as Albarracín) with a large amount of forested area. In this case, the masons from these towns used tree wood as well. Masons cut wood from Populus and Juniperus thurifera and placed approximately $1.900 \mathrm{~kg}$ of wood in each oven.

The effect of the type of fuel was evaluated. For this purpose, each combustion material (bush vs. wood) was used in a different oven. Therefore, two ovens were built.

- Phase 3: Combustion monitoring.

Temperature: Several types of Dataloggers can record temperatures up to $1000^{\circ} \mathrm{C}$ over time. We have a security margin considering the uncertainties concerning the value of extreme temperatures.
Pressure: We coudnt obtain any instruments that measure $\mathrm{pCO}_{2}$ and $\mathrm{pH}_{2} \mathrm{O}$ at temperatures over $200 \mathrm{C}$, as in our case. Instead, a pressure gauge connected to a tube inside the oven can give an estimation of the maximum pressure reached during calcination.

Humidity: At present we do not have this instrument, the firewood will be considered before the combustion procedure, comparing the weight after the combustion procedure.

- Phase 4: The role of masons during the calcination procedure.

Beginning of the calcination procedure: According to the interviewed masons, the best moment to begin the calcination depends on the season. In winter, they preferred to start in the morning because it's possible to finish in 10-14 hours before the temperature drop in the night. In summer, they preferred the evening because of fresher temperatures.

Furthermore, the interviewed masons preferred to start during days with waning moons because they observed a lower ambient pressure which affects the behavior of the smoke and results in faster combustion.

Fueling speed: Independent of the fuel type, the fire was fed as fast as possible.

Plugging the oven with mud: In some regions, a mud cover on the front part of the oven was used to concentrate the heat inside of the oven.

End of calcination procedure: After 10-14 hours of calcination, the gypsum was ready. The masons were able to determine the end of the procedure by observing the aspect of the stones in the top part of the oven. Other references were also used to determine the finishing of the calcination process, such as the moment at which have thrown on top of the oven set on fire. 


\section{Discussion}

There are important similarities among the studied ovens which were built prior to ca. 1950. The similar size, proportions and construction system enable them to be identified as primitive ovens, used with little changes in design and construction procedure since the $X^{\text {th }}$ century, a period when the oldest gypsum structures in the region were built by Muslim masons.

The combustion material can have a strong influence on the calcination products. It is necessary to study and compare the differences in the speed of combustion and heat evolution that each material produces. The presence of high $\mathrm{pH}_{2} \mathrm{O}$ it is possible with green wood.

Monitoring the combustion procedure requires of specific equipment difficult to obtain. To study only the temperature evolution would not necessarily be relevant if this parameter can not be contrasted with pressure and moisture measurements. Indeed, as an example, obtaining $\beta$-hemihydrate or a-hemihydrate [Table 01] can be just due to a difference in $\mathrm{pH}_{2} \mathrm{O}$ (not in $\mathrm{T}$ ), but might represent a tenfold increase in the strength of set gypsum.

The large amount of manual work and decisions based on experience required at least two experimented masons to control the beginning (firing of the oven) and the fire intensity, and to determine when the calcination should be finished.

The clay used in the openings of the oven and the use of green wood as fuel, with a high water content which is released during combustion, can lead to high $\mathrm{pH}_{2} \mathrm{O}$ during traditional gypsum calcination, thereby favoring the formation of a-hemihydrate, which outperforms the mechanical properties of $\beta$-hemihydrate. Similarly, $T$ in excess to those required for the conversion of gypsum into hemihydrate, may lead to the formation of a-anhydrite, whose properties once is rehydrated and transformed into gypsum might gave the use of this material for structural processes.

\section{Conclusions}

The use of an existing oven structure from Navarrete's gypsum quarry was appropriate and representative to study the calcination procedure of gypsum in a primitive traditional oven of the type used in the region until ca. 1950, when the industrialization changed the production system of gypsum.

The two different fuels, bush or tree wood, used historically depending on the region, demanded at least monitoring two individual combustions procedures to compare the results. This is why here two ovens were built.

If mud plastering is used to cover open areas of the oven, conditions during traditional gypsum preparation (calcination) can thus be similar to those achieved in autoclave ovens: high humidity and pressure.
In traditional ovens a-hemihydrate could be obtained with specific properties that enable its use as a structural and high strength material with a high durability. Similarly, if T higher than $\sim 180^{\circ} \mathrm{C}$ are reached in the oven, $a$-anhydrite can form. Its re-hydration resulting in the formation of gypsum. may also contribute to a high strength end-product that might have structural applications.

The next step in our on-going research will involve the actual firing of the two ovens and the monitoring of parameters such as $\mathrm{pH}_{2} \mathrm{O}$ and $\mathrm{T}$, as well as the analysis of the end-products formed at different heights of the oven (i.e., closer or further away from the fire).

\section{Bibliography}

ALMAGRO, A. (1986). El yeso material mudéjar, Teruel, Actas III Simposio Internacional Mudejar, pages 453-457

ARREDONDO, F. (1961). Estudio de materiales. II. El yeso, Madrid, ITCC. CSIC.

BEL-ANZUÉ, P.; VALVERDE-PALACIOS, l.; RODRIGUEZ NAVARRO, C.; SÁEZ PÉREZ, M. (2016). Estudios previos sobre la utilización del yeso de elaboración tradicional en elementos de carácter estructural, Granada, Actas de las I Jornadas de Investigadores en Formación, page 137.

BEL-ANZUE, P.; SAEZ PEREZ, M.; ALMAGRO, A.; RODRIGUEZ NAVARRO,C. Monitoring the traditional gypsum calcination process, 5th International Conference Youth in Conservation of Cultural Heritage, Madrid 21-23 September 2016, MNCARS (in press).

FREIER, W.; VOIGT, A. (2003). Analysis of the relationship between particle size distribution of a-calcium sulfate hemihydrate and compressive strength of set plaster Using grey model. Powder Technology 200, 136-143

GONZALVO VALLESPÍ, Á. (1996). La Memoria Cinematográfica del Espectador, pág. 34

LA SPINA, V.; MILETO, C. YVEGAS, F. (2013)“The historical renderings of Valencia (Spain): An experimental study". Journal of Cultural Heritage, vol. 14, No35, pp. 44-51.

MAORAD, A. Y RIVAS, F. (2002). Técnicas Tradicionales de Construcción en Aragón, Zaragoza, Archivo de Etnogáfico de Los Monegros.

MILETO, C.; VEGAS, F. Y LA SPINA, V. (2011). "Is gypsum external rendering possible? The use of gypsum mortar for rendering historic façades of Valencia's city centre". Advanced Materials Research, vols. 250-253, pp. 1301-1304.

MONESMA, E. (2001). "Técnica de construcción de cielo raso". Serie audiovisual- La construcción tradicional. Escuela Oficial de Aparejadores. Huesca.

MONESMA, E. (2006). Técnica de construcción de los hornos de yeso, CD-ROM, Huesca. 
RUBIO DOMENE, Ramón Francisco (2006). El material del yeso: comportamiento y conservación. Cuadernos de Restauración, n6.

SIEVERT T., WOLTER A., SINGH N.B. (2005). Hydration of anhydrite of gypsum (CaSO4.II) in a ball mil. Cement and Concrete Research 35, $623-630$

SINGH N.B., MIDDENDORF B (2007). Calcium sulphate hemihydrate hydration leading to gypsum crystallization. Science Direct. Progress in Crystal Growth and Characterization of Materials 53, 57-77

YE Q., et al., (2011)."Effect of particle size distribution on the hydration and compressive strength development of a-calcium sulfate hemihydrate paste", Powder Technology, n. 207, pages 208-214.

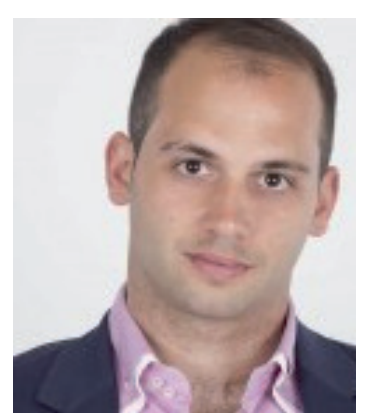

\title{
Pedro Bel-Anzué
}

pedro.bel.anzue@gmail.com

Architect and civil engineer. Specialized in sustainable construction and heritage. He has design and built several green-constructions in Spain. Nowadays he is completing his PhD in Granada University. Dept. of Mineralogy and Petrology, Faculty of Science, University of Granada, Campus Fuentenueva s/n, 18071Granada, Spain.

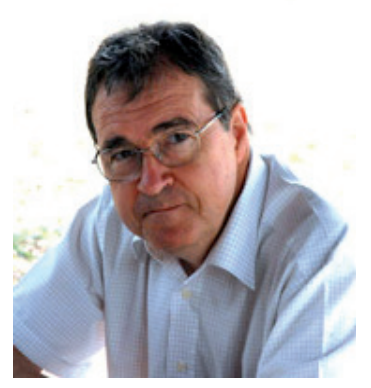

\section{Antonio Almagro}

\author{
aalmagro@eea.csic.es
}

Architect Research Professor, Consejo Superior de Investigaciones Científicas (CSIC). School of Arabic Studies. Cuesta del Chapiz, 22, 18010 Granada, Spain. 


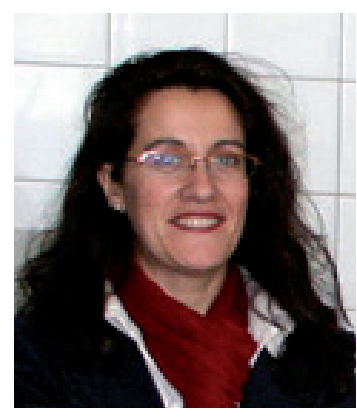

\section{Maria Paz Sáez Pérez}

mpsaez@ugr.es

Geologist and civil engineer. Professor of the University of Granada. Department of Architectural Technology. Faculty of Technical Architecture, University of Granada, Campus Fuentenueva s/n, 18071Granada, Spain.

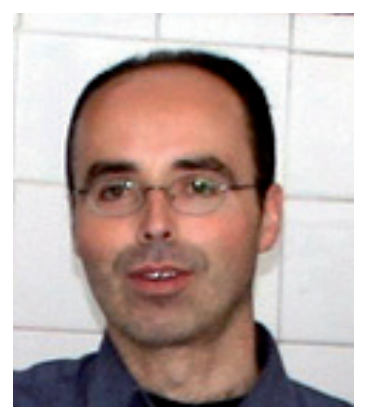

\section{Carlos Rodriguez-Navarro}

carlosrn@ugr.es

Geologist Full Professor of the University of Granada. Department of Mineralogy and Petrology. Dept. of Mineralogy and Petrology, Faculty of Science, University of Granada, Campus Fuentenueva s/n, 18071Granada, Spain. 